Research Article

\title{
Variation in extragenic repetitive DNA sequences in Pseudomonas syringae and potential use of modified REP primers in the identification of closely related isolates
}

\author{
Elif Çepni ${ }^{1}$ and Filiz Gürel ${ }^{1,2}$ \\ ${ }^{1}$ Department of Molecular Biology and Genetics, Faculty of Sciences, Istanbul University, Istanbul, Turkey. \\ ${ }^{2}$ Center for Biotechnology and Genetic Engineering Research and Application, Istanbul University, Istanbul, \\ Turkey.
}

\begin{abstract}
In this study, Pseudomonas syringe pathovars isolated from olive, tomato and bean were identified by species-specific PCR and their genetic diversity was assessed by repetitive extragenic palindromic (REP)-PCR. Reverse universal primers for REP-PCR were designed by using the bases of A, T, G or C at the positions of 1, 4 and 11 to identify additional polymorphism in the banding patterns. Binding of the primers to different annealing sites in the genome revealed additional fingerprint patterns in eight isolates of $P$. savastanoi pv. savastanoi and two isolates of $P$. syringae pv. tomato. The use of four different bases in the primer sequences did not affect the PCR reproducibility and was very efficient in revealing intra-pathovar diversity, particularly in $P$. savastanoi pv. savastanoi. At the pathovar level, the primer BOX1AR yielded shared fragments, in addition to five bands that discriminated among the pathovars $P$. syringae pv. phaseolicola, $P$. savastanoi pv. savastanoi and $P$. syringae pv. tomato. REP-PCR with a modified primer containing $C$ produced identical bands among the isolates in a pathovar but separated three pathovars more distinctly than four other primers. Although REP-and BOX-PCRs have been successfully used in the molecular identification of Pseudomonas isolates from Turkish flora, a PCR based on inter-enterobacterial repetitive intergenic concensus (ERIC) sequences failed to produce clear banding patterns in this study.
\end{abstract}

Key words: bacterial identification, biodiversity, PCR.

Received: October 11, 2011; Accepted: April 9, 2012.

\section{Introduction}

The Pseudomonas syringae group belongs to the family Pseudomonaceae and causes diseases in nearly all species of cultivated plants, including horticultural crops and ornamental and fruit trees (Young et al., 1996). Many of these pathovars, which are widely distributed on different plant parts (shoots, leaves, buds, pots, etc.), are highly specific to one or a few related plant species and cause a variety of symptoms such as watersoaking, hypertrophic growth, cankers, chlorosis and necrosis (Murillo and Sesma, 2001). The Pseudomonas syringae group also has the best described epiphytic growth among phytopathogenic bacteria (Hirano and Upper, 2000). One member of this group, Pseudomonas savastanoi, has been classified as a species rather than a pathovar based on DNA hybridization and ribotyping studies (Gardan et al., 1999). Pathogenic strains of $P$. savastanoi pv. savastanoi infect olive trees and cause olive knot disease.

Send correspondence to Filiz Gürel. Department of Molecular Biology and Genetics, Faculty of Sciences, Istanbul University, Vezneciler 34134, Istanbul, Turkey. E-mail: filiz@ istanbul.edu.tr.
Pseudomonas syringae has previously been identified based on fatty acid profiling (Stead, 1992), protein analyses (Van Zyl and Steyn, 1990) and plasmid profiles (King, 1989). More recently, DNA fingerprinting methods such as randomly amplified polymorphic DNA (RAPD), amplified fragment length polymorphism (AFLP) (Cirvilleri et al., 2006; Sisto et al., 2007), restriction fragment length polymorphism (RFLP) (Manceau and Horvais, 1997) and insertion sequence-based methods (Weingart and Völksch, 1997; Oguiza et al., 2004; Quesada et al., 2008) have been used to diagnose and genotype $P$. syringae strains and pathovars of different origins. However, none of these methods is ideal for such identifications since each of them has technical disadvantages. PCR-based methods are still the most preferred approach for bacterial genotyping because their low-cost and high output make them efficient in providing new genomic sequence information. Bacterial extragenic non-coding regions have been widely used to obtain specific fingerprints that are more informative and reproducible than RAPD markers.

Repetitive extragenic palindromic (REP) sequences or elements were first described in Escherichia coli and 
Salmonella typhimurium operons (Higgins et al., 1982). The palindromic nature of these elements and their ability to form stable stem-loop structures in transcribed RNA suggest that they may have regulatory roles associated with transcriptional termination, mRNA stability and chromosomal organization in bacteria (Versalovic et al., 1991). Amplifications based on REP elements in conjunction with other related families of repetitive elements, such as enterobacterial repetitive intergenic concensus (ERIC) and BOX sequences, have been exploited in the molecular identification of bacteria pathogenic to plants. Three types of PCR (known as Rep-PCR) based on these elements have been used together and specific reproducible fingerprints were obtained more quickly and more cost-effectively than with other methods such as AFLP and RFLP (Louws et al., 1999).

Rep-PCR genotyping has been applied to many species of plant pathogenic bacteria but has limited ability in discriminating among pathovars and closely related isolates (de Bruijn, 1992; Judd et al., 1993; Woods et al., 1993). One reason for this poor discriminatory power is that REP-PCR may produce monomorphic bands in bacterial samples collected from distant geographic locations. Another reason is the variability in the PCR amplification products obtained for the three types of repetitive elements in bacterial genomes. The universal primers of REP-PCR amplify the intervening DNA between two adjacent repetitive elements. We have modified reverse REP-PCR primers produced by substituting $\mathrm{A}, \mathrm{T}, \mathrm{G}$ or $\mathrm{C}$ at three different positions to yield four primer combinations. By changing the annealing sites in the genome we obtained highly polymorphic fingerprint patterns among $P$. savastanoi pv. savastano $i$ isolates collected from olive trees. In the present study, we used a set of these primers with high discriminatory power to distinguish isolates and pathovars of $P$. savastanoi pv. savastanoi, $P$. syringae pv. phaseolicola and $P$. syringae pv. tomato.

\section{Materials and Methods}

\section{Bacterial strains}

Pseudomonas syringae pathovars of tomato, bean and olive (Pss-14) (Table 1) were kindly provided by Prof. Hatice Ozaktan (Ege University), Dr. Aynur Karahan (Ankara Plant Protection Central Research Institute) and Prof. Kemal Benlioglu (Adnan Menderes University), respectively. All of the pathovars originated in Turkey except for NCPPB-52, which originated in the United Kingdom (UK). Pseudomonas savastanoi pv. savastanoi isolates other than Pss-14 were isolated from olive knots of branches obtained from nurseries in the Marmara and Aegean regions (western and northwestern Turkey).
Table 1 - Pseudomonas savastanoi and $P$. syringae isolates used in this study.

\begin{tabular}{lcccc}
\hline Pathovar & Strain & Isolate & Host & Location \\
\hline $\begin{array}{l}\text { Pseudomonas } \\
\text { savastanoi }\end{array}$ & pv. savastanoi & Pss-14 & Olive & Antalya \\
& pv. savastanoi & Pss-7A & Olive & Orhangazi \\
& pv. savastanoi & Pss-8A & Olive & Orhangazi \\
& pv. savastanoi & Pss-9A & Olive & Orhangazi \\
& pv. savastanoi & Pss-7D & Olive & Orhangazi \\
& pv. savastanoi & Pss-4B & Olive & Orhangazi \\
& pv. savastanoi & Pss-M9 & Olive & Akhisar \\
Pseudomonas & pv. savastanoi & Pss-M25 & Olive & Akhisar \\
\hline syringae & pv. tomato & Pst & Tomato & Izmir \\
& pv. phaseolicola & Psp-3 & Bean & Ankara \\
& pv. phaseolicola & Psp-18 & Bean & Ankara \\
& pv. phaseolicola & Psp-R52 & Bean & Izmir \\
& pv. phaseolicola & NCPPB-52 & Bean & UK \\
\hline
\end{tabular}

\section{Isolation and identification of $P$. savastanoi pv. savastanoi}

P. savastanoi pv. savastanoi was isolated as described by Saygili (1995). Briefly, knots were washed in tap water and cut into small fragments $(2 \times 2 \mathrm{~mm})$ with a sterile scalpel. The fragments were placed in sterile tubes containing $3 \mathrm{~mL}$ of sterile distilled water and left at room temperature for $30 \mathrm{~min}$. Subsequently, $\sim 20 \mu \mathrm{L}$ aliquots were streaked on King B (KB) medium (King et al., 1954) in petri dishes and incubated at $28{ }^{\circ} \mathrm{C}$ for $72 \mathrm{~h}$. The suspected colonies of $P$. savastanoi pv. savastanoi, which were flat and 2-3 $\mathrm{mm}$ in diameter with irregular margins and a grayish-white color, were selected and spread again on selective PVF-1 medium (Kado and Heskett, 1970) followed by incubation at $28^{\circ} \mathrm{C}$ for $72 \mathrm{~h}$. This subculturing was repeated 2-3 times to purify the isolates. The isolates were also Gram stained. All of the $P$. syringae strains identified (Table 1) were cultured in appropriate medium and stored at $-80{ }^{\circ} \mathrm{C}$.

For species-specific PCR and repetitive-PCR, a single colony of each strain of $P$. syringae was used as a source of template DNA. Primer sequences (Pss1: 5'-TGGGTTGCTACTTGTACCGGA-3' and Pss2: 5'-CCGTGTACTACGTTCAGCGAG-3') corresponding to the ptz (Basim and Ersoy, 2001) and iaaL (IAALF: 5'-GGCACCAGCGGCAACATCAA-3' and IAALR: 5'-CGCCCTCGGAACTGCCATAC-3') genes (Penyalver et al., 2000) were used for $P$. savastanoi pv. savastanoi. We also used primers derived from the $\operatorname{argK}$ (Psp1: 5'-CCATGAAGATTACAAGCCTG-3' and Psp2: 5'-GCTAGCTATCAGGGGACGAC-3') (Mosqueda-Cano and Herrera-Esterella, 1997) and cfI (Pst1: 5'-GGCGCTCCCTCGCACTT-3' and Pst2: 5'-GGTATTGGCGGGGGTGC-3') (Bereswill et al., 
1994) genes for $P$. syringae pv. phaseolicola and $P$. syringae pv. tomato, respectively.

The reaction mixture consisted of 1x Ex-Taq DNA polymerase buffer (Takara), $2.5 \mathrm{mM} \mathrm{MgCl}_{2}, 200 \mu \mathrm{M}$ of each dNTP, 0.5 units of Ex-Taq DNA polymerase (Takara) and $50 \mathrm{pmol}$ of each primer in a final volume of $25 \mu \mathrm{L}$. The PCR conditions included an initial denaturation at $95^{\circ} \mathrm{C}$ for 5 min, followed by 35 cycles of $95^{\circ} \mathrm{C}$ for $1 \mathrm{~min}, 55^{\circ} \mathrm{C}$ for $1 \mathrm{~min}$ and $72{ }^{\circ} \mathrm{C}$ for $2 \mathrm{~min}$, with a final extension at $72{ }^{\circ} \mathrm{C}$ for $10 \mathrm{~min}$. Three independent amplifications were done for each sample in a Techne thermocycler and the PCR products were separated on $1 \%$ agarose gels and photographed under UV illumination.

\section{Repetitive-PCR}

Universal primers based on REP sequences were used for REP-PCR (Versalovic et al., 1991). The REP primers were modified by inserting a base (A, T, G or C) at one of three $\mathrm{N}$ positions in the reverse Rep-2-Dt primer (Table 2). We examined five primer sets that included different combinations of REP primers (Rep-1R-Dt/Rep-2-Dt, Rep-1RDt/Rep-2A, Rep-1R-Dt/Rep-2T, Rep-1R-Dt/Rep-2G and Rep-1R-Dt/Rep-2C). The primer used for BOX-PCR was BOXA1R (5'-CTACGGCAAGGCGACGCTGACG-3') (Versalovic et al., 1994) while those used for ERIC-PCR were ERIC1 (5'-ATGTAAGCTCCTGGGGATTCAC-3') and ERIC2 (5'-AAGTAAGTGACTGGGGTGAGCG-3') (Versalovic et al., 1991).

The reaction mixture consisted of 1x Ex-Taq DNA polymerase buffer (Takara), $3 \mathrm{mM} \mathrm{MgCl}_{2}, 200 \mu \mathrm{M}$ of each dNTP, 1 unit of Ex-Taq DNA polymerase (Takara) and $50 \mathrm{pmol}$ of each primer in a final volume of $25 \mu \mathrm{L}$. The PCR conditions included an initial denaturation at $94^{\circ} \mathrm{C}$ for 5 min followed by 40 cycles of $94{ }^{\circ} \mathrm{C}$ for $1 \mathrm{~min}, 34^{\circ} \mathrm{C}$ for $1 \mathrm{~min}$ and $72{ }^{\circ} \mathrm{C}$ for $2 \mathrm{~min}$, with a final extension at $72{ }^{\circ} \mathrm{C}$ for $15 \mathrm{~min}$. Two independent amplifications were done for each sample in a Creon T-cy thermocycler and the PCR products were separated on $1.5 \%$ agarose gels and photographed under UV illumination.

\section{Data analysis}

The bands for each strain and primer were scored as absent (0) or present (1) and the resulting fingerprints were

Table 2 - Universal and modified primers used for REP-PCR in this study.

\begin{tabular}{lc}
\hline Primer & Primer sequence (5'-3') \\
\hline Rep-1R-Dt & IIINCGNCGNCATCNGGC (forward) \\
Rep-2-Dt & NCGNCTTATCNGGCCTAC \\
Rep-2A & ACGACTTATCAGGCCTAC \\
Rep-2T & TCGTCTTATCTGGCCTAC \\
Rep-2G & GCGGCTTATCGGGCCTAC \\
Rep-2C & CCGCCTTATCCGGCCTAC \\
\hline
\end{tabular}

Letters in bold type indicate the bases that were altered in each primer at the positions indicated by $\mathrm{N}$ (underlined) in the first primer. compared using MVSP 3.2 software. Jaccard's coefficient of similarity index (Jaccard, 1908) was used to calculate similarity distances. Cluster analysis was done using the unweighted pair-group method with arithmetic average (UPGMA).

\section{Results}

Seven $P$. savastanoi pv. savastanoi isolates were obtained from 110 olive knots after elimination of suspected colonies. Isolates 7A and 7D (Table 1) were closely related samples obtained from two knots on the same branch. The bacteria were Gram-negative and grew well on selective PVF-1 medium. All of the isolates produced the expected bands of $684 \mathrm{bp}$ and $454 \mathrm{bp}$ with the primer pairs Pss1/Pss2 and IAALF/IAALR, respectively (Figure 1A,B). Bands of $650 \mathrm{bp}$ and $1000 \mathrm{bp}$ were amplified in all $P$. syringae pv. tomato and $P$. syringae pv. phaseolicola strains with primer pairs Pst1/Pst2 and 62a/63a, respectively (data not shown).

$P$. savastanoi pv. savastanoi genomic fingerprints were obtained with all of the five REP-PCR primer sets. Three primer sets (Rep-1R-Dt/Rep-2-Dt, Rep-1R-Dt/Rep$2 \mathrm{~A}$ and Rep-1R-Dt/Rep-2C) were more polymorphic among the isolates than the other two sets (Rep-1RDt/Rep-2T and Rep-1R-Dt/Rep-2G) (Figure 2). The corresponding PCR products ranged in size from $200 \mathrm{bp}$ to $3000 \mathrm{bp}$ (Figure 2). In two P. syringae pv. tomato strains from Ankara and Izmir, the REP primer sets produced very distinctive fingerprints, particularly with primer pairs Rep-1R-Dt/Rep-2-Dt, Rep-1R-Dt/Rep-2G and Rep-1R$\mathrm{Dt} /$ Rep-2C (Figure 3). The corresponding PCR products ranged in size from $\sim 200 \mathrm{bp}$ to $>1500 \mathrm{bp}$.

At the pathovar level, each REP primer set was screened for well-defined, reproducible bands. The Rep1R-Dt and Rep-2C primer pairs distinguished among pathovars, as shown in Figure 4A. Amplification with the BOXA1R primer yielded PCR products of 270-2100 bp in each pathovar (Figure 4B). The arrows in Figure 4B indicate polymorphic bands for tomato, olive and bean patho-

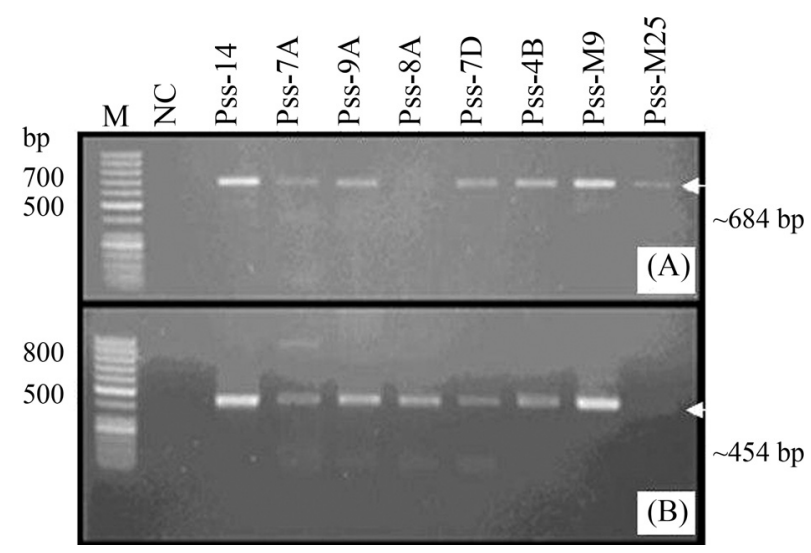

Figure 1 - Species-specific PCR fragments of $P$. savastanoi pv. savastanoi isolates obtained with (A) Pss1/Pss2 and (B) IAALF/IAALR primers. M - DNA ladder, NC - negative control (no DNA template). 

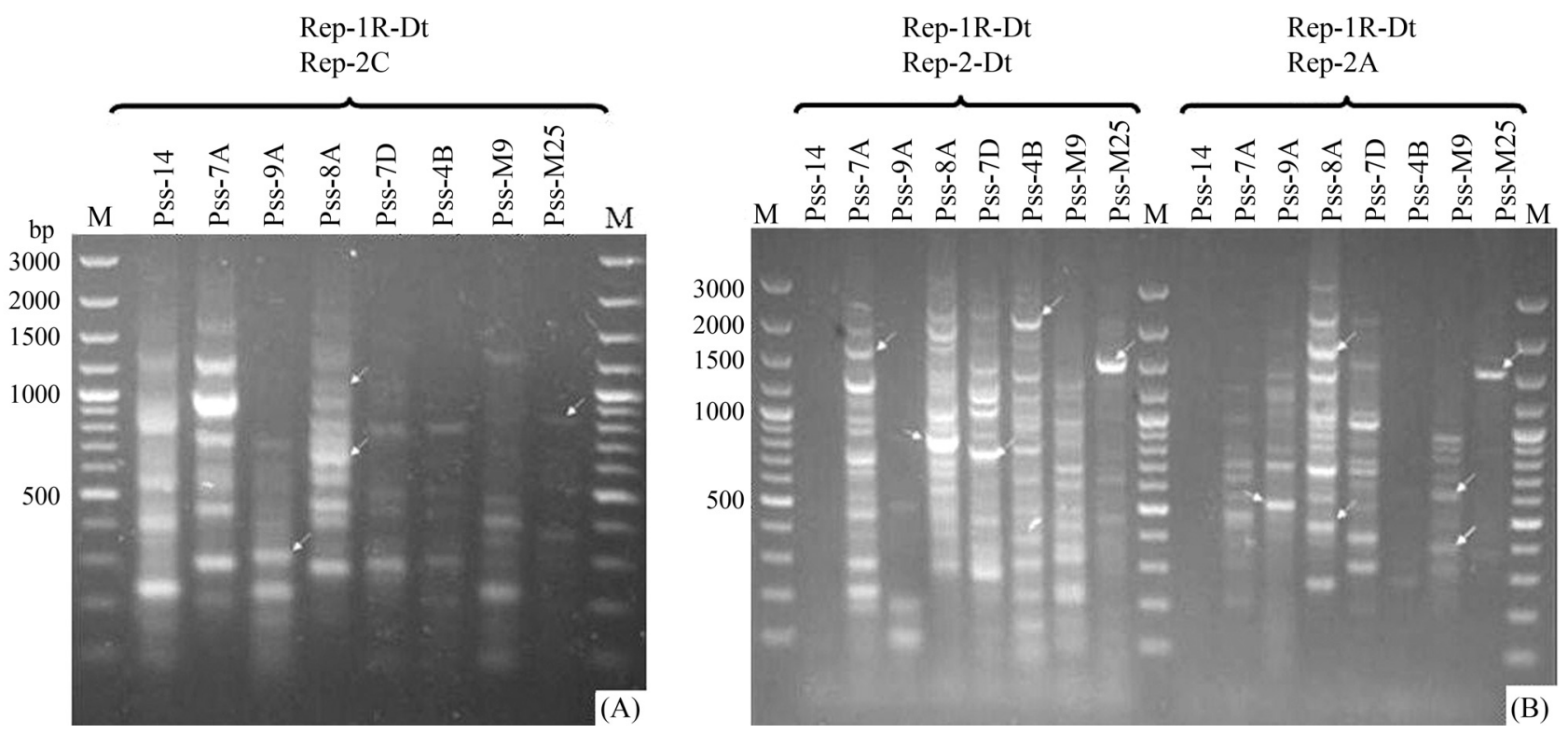

Figure 2 - Repetitive-PCR fragments of $P$. savastanoi pv. savastanoi isolates obtained with different REP primer combinations. (A) Rep-1R-Dt and Rep-2C, (B) Rep-1R-Dt and Rep-2-Dt, and Rep-1R-Dt and Rep-2A. M - DNA ladder.

vars of P. syringae (Psp-18, Pss-14 and Pst-101, respectively). REP-PCR yielded a higher number of bands and more complex patterns than BOX-PCR. P. syringae pv. phaseolicola isolates were distinguishable from all the other isolates by the size of their PCR products (200-700 bp; lanes 1-4 in Figure 4B). Exceptions included the $P$. syringae pv. phaselicola pathovar from Ankara (Psp-3), which lacked the 700 bp band, and Psp-18, which

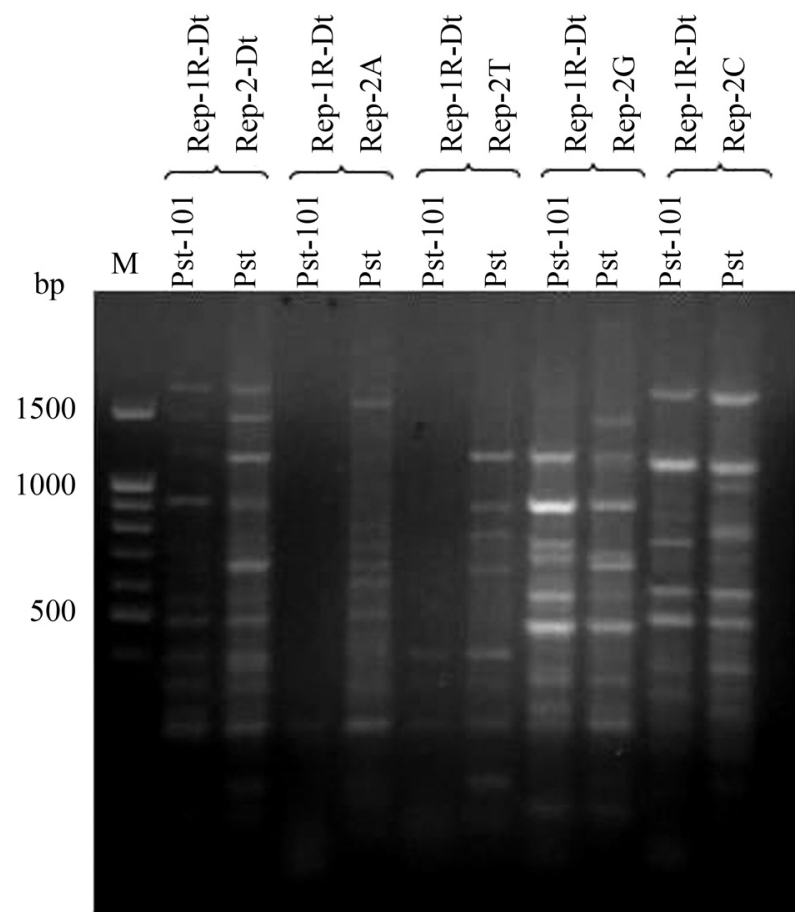

Figure 3 - Repetitive-PCR fragments of $P$. syringae pv. tomato isolates obtained with different REP primer combinations. M - DNA ladder. produced two additional bands of $\sim 2100 \mathrm{bp}$ and $1500 \mathrm{bp}$ (lane 4 in Figure 4B). P. savastanoi pv. savastanoi could be distinguished by a single specific fragment of $700 \mathrm{bp}$ (lane 5 in Figure 4B). P. syringae pv. tomato strains differed completely from the other pathovars and from each other by producing two slightly different bands of $\sim 250 \mathrm{bp}$ (lanes 6 and 7 in Figure 4B). In contrast to REP-PCR which produced several common bands in tomato pathovars, no common bands were observed with BOX-PCR (lanes 6 and 7 in Figure 4B). The monomorphic and polymorphic bands observed with BOXA1R in $P$. syringae pv. phaselicola isolates of Turkish and UK origin demonstrated the conserved nature of BOX elements in the $P$. syringae genome. No observable inter-ERIC fingerprints were obtained in six local isolates or in isolate NCPPB-52 of UK origin.

The UPGMA dendrogram revealed two major divisions among the isolates (Figure 5) the $P$. syringae pv. phaseolicola pathovars formed a group that included $P$. savastanoi while the $P$. syringae pv. tomato isolates formed a second group, with a genetic similarity of 0.25 between groups. The approximate genetic diversity among all isolates was $80 \%$.

\section{Discussion}

The precise identification of $P$. syringae pathovars, which are widespread pathogens, is important for basic studies related to genetic polymorphism and adequate agricultural management. Species-specific PCR is a powerful method for the rapid, convenient diagnosis of microbial pathogens in laboratory samples derived from plants with symptomatic phenotypes. The Pss1/Pss2 primer pair used by Basim and Ersoy (2001) for the molecular identification 

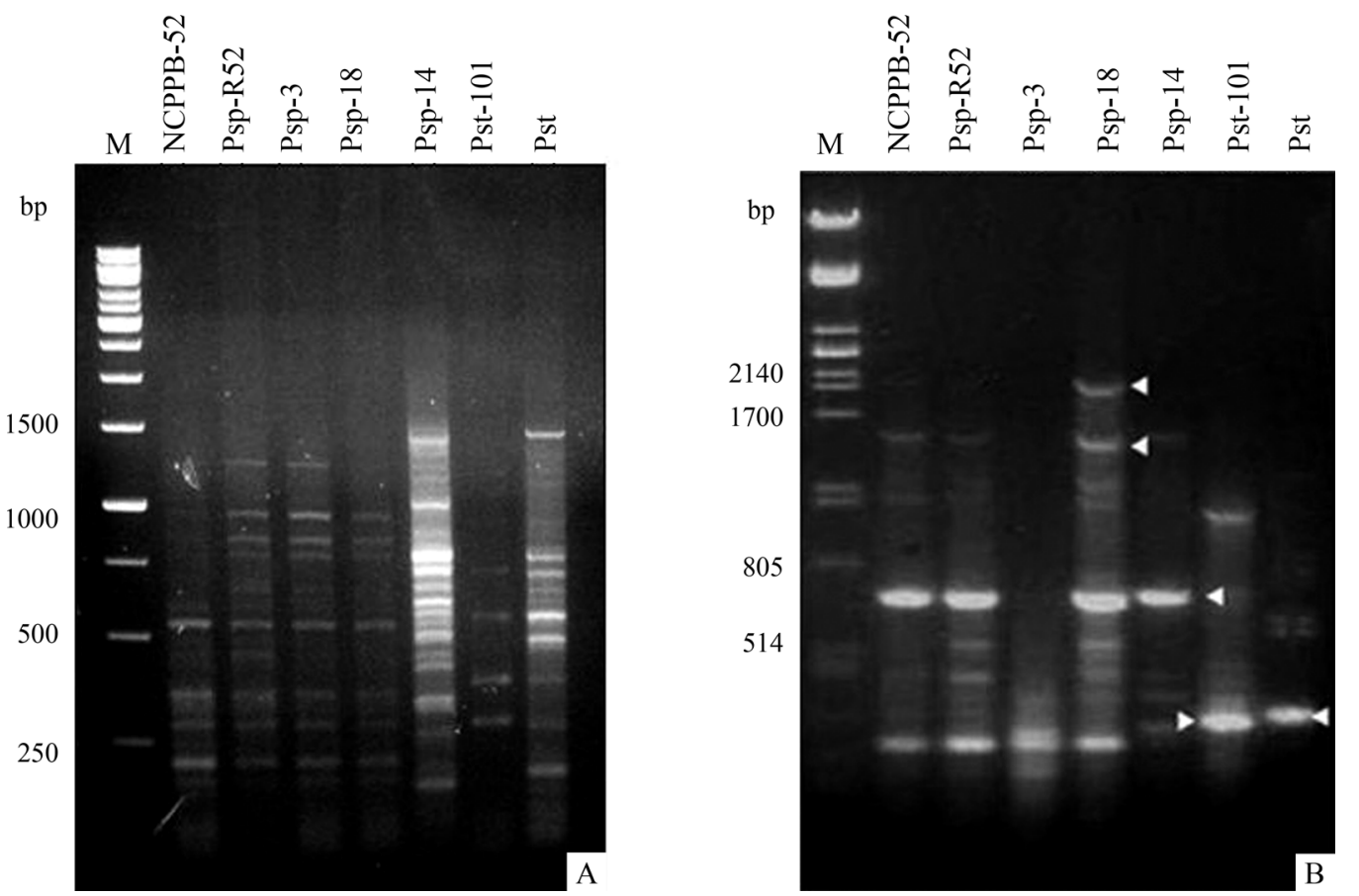

Figure 4 - REP-PCR fingerprints of P. syringae pathovars obtained with Rep-1R-Dt and Rep-2C primers (A) and BOX-PCR fingerprints of $P$. syringae pathovars (B). M - $1 \mathrm{~kb}$ DNA ladder for (A) and $\lambda$ DNA/PstI DNA ladder for (B).

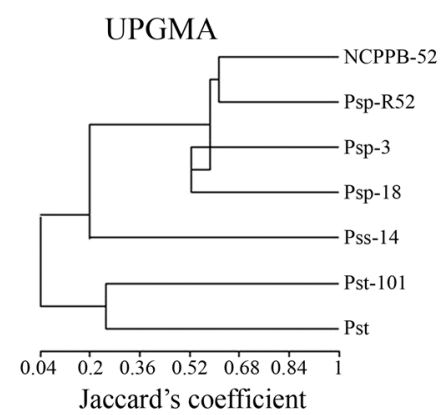

Figure 5 - Approximate relationships among $P$. syringae pathovars based on UPGMA analysis of the combined data sets obtained with REP-PCR and BOX-PCR primers.

of $P$. savastanoi pv. savastanoi was particularly useful in the present study. Another set of primers (IAALF and IAALR for the iaaL gene) (Penyalver et al., 2000) was also useful for identifying $P$. savastanoi pv. savastanoi strains from naturally infected and asymptomatic olive trees. The use of combinations of modified primers in REP-PCR enhanced the range of DNA fingerprints that could be detected. In this approach, it is the reverse primers rather than the forward primers that bind to the different annealing sites in the genome to produce the diversity of DNA amplicons.

The discriminatory potential of rep-PCR for different P. syringae pathovars has been shown in previous reports (Louws et al., 1994; Weingart and Völksch, 1997; Stead et al., 2004; Vicente and Roberts, 2007; Kaluzna et al., 2010). A pathovar is defined as a subspecific group of strains that can infect particular plants within a certain genus or species. Intra-pathovar diversity is generally of two types, namely, (a) isolates from the same pathovar that may have identical REP, BOX and ERIC fingerprints and (b) isolates that do not share common rep-PCR banding patterns (Louws et al., 1994). The first of these two groups was initially identified in an analysis of samples that included $P$. syringae pv. morsprunorum and Xanthomonas campestris pv. phaseoli; in this case, the number of monomorphic REP-PCR bands was greater than that of polymorphic bands in 12 isolates of $P$. syringae pv. morsprunorum, $P$. syringae pv. syringae and $P$. syringae pv. tomato from distant locations in the United States (Louws et al., 1994). As shown here, the insertion of $\mathrm{G}$ and $\mathrm{C}$ in Rep2-Dt primers at positions 1, 4 and 11 yielded additional different sized bands in REP-PCR of $P$. syringae pv. tomato DNA (Figure 3). Despite the limited number of strains examined here, the use of modified REP-PCR primers enhanced the detection of intra-pathovar diversity by expanding the number of annealing sites. There was a clear difference in the the ability of the three types of rep-PCR to detect genetic diversity in P. syringae. Scortichini et al. (2004) reported that REP primers were highly discriminatory in distinguishing among $P$. savastanoi isolates from Italy. The P. syringae genome contains high copy numbers of REP elements that are related to insertion sequence elements (ISI) (Tobes and Pareja, 2006). This feature of REP elements may explain the abundance and diversity of fingerprints seen upon amplification of the intervening regions. 
In our work, $P$. s. pv. savastanoi isolates showed more polymorphism than tomato and bean isolates by using REP primer combinations. One of the reasons for that is the bacterial population which was isolated from knots could be contained both epiphytic and pathogenic strains of $P$. savastanoi. In addition, $P$. savastanoi pv. savastano strains may have diverged extensively during their coevolution with olive trees (Olea europaea) (Scortichini et al., 2004), particularly since the latter are widely distributed and well adapted in western Turkey.

The BOXA1R universal primer identified genetically distinct $P$. syringae pathovars and could therefore be potentially useful as a diagnostic tool, although the number of fingerprints it yielded was considerably lower than that obtained with REP-PCR. No inter-ERIC fingerprints were obtained for any of the isolates. Although they have been used in P. syringae genotyping (Louws et al., 1994; Scortichini et al., 2004; Vicente and Roberts, 2007; Kaluzna et al., 2010), ERIC sequences have been found only in the Enterobacteriaceae and Vibrio species (Wilson and Sharp, 2006). Theoretically, ERIC primers bind to sequences between ERIC copies and produce fragments of variable length, depending on the positions of these conserved elements. The amplifications reported for ERIC-PCR in several reports may have arisen from randomly binding primers and consist of homologous bands shared by isolates or pathovars. The random nature of ERIC-PCR can also be seen in the successful amplification of fungal DNA (Gürel et al., 2010), even though ERIC elements have not yet been reported in fungal DNA.

The availability of low-cost, fast and reliable methods for screening genetic diversity is a valuable tool in the diagnosis of local bacterial populations. The work described here provides a procedure for the isolation of $P$. savastanoi $p v$. savastoni isolates from olive knots and for reliable identification using species-specific primers. The use of modified primers allows the genetic variation among isolates in a particular environment to be monitored in a short time by colony PCR. The most important advantage in this approach is that the primer combinations enhance the possibility of obtaining distinct and unique banding patterns among the genotypes that can extend our understanding of the genetic diversity of these organisms. As shown here, the banding patterns obtained with a cytosine-containing primer (Rep2-C) yielded information on genetic relationships and led to the identification of distinct pathovar groups (Figure 5). Variations based on extragenic repetitive DNA in local isolates of $P$. savastanoi may provide clues to the nature of mutations associated with REP elements and the importance of the latter as regulators of bacterial gene expression.

\section{Acknowledgments}

We thank Prof. Kemal Benlioglu, Prof. Hatice Ozaktan and Dr. Aynur Karahan for providing the bacterial strains used in this study. This work was supported by the Research Fund of Istanbul University (project no. T719/30062005).

\section{References}

Basim H and Ersoy A (2001) Identification of Pseudomonas savastanoi pv. savastanoi, olive knot pathogen, by polymerase chain reaction. In: Abstracts, Phytopathology Salt Lake 2001 APS/SON/MSA Joint Meeting, 25-29 August, 2001, Abstract S6.

Bereswill S, Bugert P, Völksch B, Ullrich M, Bender CL and Geider K (1994) Identification and relatedness of coronatine-producing Pseudomonas syringae pathovars by PCR analysis and sequence determination of the amplification products. Appl Environ Microbiol 60:2924-2930.

Cirvilleri G, Scuderi G, Bonaccorsi A and Scortichini M (2006) Molecular characterization of Pseudomonas syringae $p \mathrm{v}$. syringae strains from different host plants using fluorescent amplified fragment length polymorphism. J Plant Pathol 88:327-331.

de Bruijn FJ (1992) Use of repetitive (repetitive extragenic palindromic and enterobacterial repetitive intergenenic consensus) sequences and the polymerase chain reaction to fingerprint the genomes of Rhizobium meliloti isolates and other soil bacteria. Appl Environ Microbiol 58:2180-2187.

Gardan L, Shafik H, Belouin S, Broch R, Grimont F and Grimont PAD (1999) DNA relatedness among the pathovars of Pseudomonas syringae and description of Pseudomonas tremae sp. nov. and Pseudomonas cannabina sp. nov. (ex Sutic and Dowson 1959). Int J Syst Bacteriol 49:469-478.

Gürel F, Albayrak G, Diken O, Çepni E and Tunali B (2010) Use of Rep-PCR for genetic diversity analyses in Fusarium culmorum. J Phytopathol 92:781-787.

Higgins CF, Ames GFL, Barnes WM, Clement JM and Hofnung M (1982) A novel intercistronic regulatory element of prokaryotic operons. Nature 298:760-762.

Hirano SS and Upper CD (2000) Bacteria in the leaf ecosystem with emphasis on Pseudomonas syringae - A pathogen, ice nucleus, and epiphyte. Microbiol Mol Biol Rev 64:624-653.

Jaccard P (1908) Nouvelles recherches sur la distribution florale. Bull Soc Vandoise Sci Nat 44:223-270.

Judd AK, Schneider M, Sadowsky MJ and de Bruijn FJ (1993) Use of repetitive sequences and the polymerase chain reaction technique to classify genetically related Bradyrhizobium japonicum serocluster 123 strains. Appl Environ Microbiol 59:1702-1708.

Kado CI and Heskett MG (1970) Selective media isolation of Agrobacterium, Corynebacterium, Erwinia, Pseudomonas and Xanthomonas. Phytopathology 60:969-976.

Kaluzna M, Ferrante P, Sobiczewski P and Scortichini M (2010) Characterization and genetic diversity of Pseudomonas syringae from stone fruits and hazelnut using repetitive-PCR and MLST. J Plant Pathol 92:781-787.

King GJ (1989) Plasmid analysis and variation in Pseudomonas syringae. J Appl Bacteriol 67:489-496.

King EO, Ward NK and Raney DE (1954) Two simple media for the detection of pyocyanin and fluorescein. J Lab Clin Med 44:301-307.

Louws FJ, Fulbright DW, Stephens CT and de Bruijn FJ (1994) Specific genomic fingerprints of phytopathogenic 
Xanthomonas and Pseudomonas pathovars and strains generated with repetitive sequences and PCR. Appl Environ Microbiol 60:2286-2295.

Louws FJ, Rademaker JLW and de Bruijn FJ (1999) The three Ds of PCR-based genomic analysis of phytobacteria: Diversity, detection, and disease diagnosis. Annu Rev Phytopathol 37:81-125.

Manceau C and Horvais A (1997) Assessment of genetic diversity among strains of Pseudomonas syringae by PCR-restriction fragment length polymorphism analysis of rRNA operons with special emphasis on P. syringae pv. tomato. Appl Environ Microbiol 63:498-505.

Mosqueda-Cano G and Herrera-Esterella L (1997) A simple and efficient PCR method for specific detection of Pseudomonas syringae pv. phaseolicola in bean seeds. World J Microbiol Biotechnol 13:463-467.

Murillo J and Sesma A (2001) The biochemistry and molecular genetics of host range definition: Pseudomonas syringae. $\mathrm{J}$ Phytopathol Medit 40:3-26.

Oguiza JA, Rico A, Rivas LA, Sutra L, Vivian A and Murillo J (2004) Pseudomonas syringae pv. phaseolicola can be separated into two genetic lineages distinguished by the possession of the phaseolotoxin biosynthetic cluster. Microbiology 150:473-482.

Penyalver R, Garcia A, Ferrer A, Bertolini E and Lopez MM (2000) Detection of Pseudomonas savastanoi pv. savastanoi in olive plants by enrichment and PCR. Appl Environ Microbiol 66:2673-2677.

Quesada JM, Perez-Martinez I, Ramos C, Lopez MM and Penyalver R (2008) IS53: An insertion element for molecular typing of Pseudomonas savastanoi pv. savastanoi. Res Microbiol 159:207-215.

Saygili H (1995) Fitobakteriyoloji. E.U. Ziraat Fakültesi Bitki Koruma Bölümü, Izmir, Turkey, 9944-5822-0-2.

Scortichini M, Rossi MP and Salerno M (2004) Relationship of genetic structure of Pseudomonas savastanoi pv. savastanoi populations from Italian olive trees and patterns of host genetic diversity. Plant Pathol 53:491-497.

Sisto A, Cipriani MG, Tegli S, Cerboneschi M, Stea G and Santilli E (2007) Genetic characterization by fluorescent AFLP of Pseudomonas savastanoi pv. savastanoi strains isolated from different host species. Plant Pathol 56:366-372.

Stead DE (1992) Grouping of plant pathogenic and some other Pseudomonas species by using cellular fatty acid profiles. Int J Syst Bacteriol 42:281-295.
Stead DE, Simpkins SA, Weller SA, Hennesy J, Aspin A, Stanford H, Smith NC and Elphinstone JG (2004) Classification and identification of plant pathogenic Pseudomonas species by REP-PCR derived genetic fingerprints. In: Iacobellis NS, Collmer A, Hutcheson SW, Mansfield JW, Morris CE, Murillo J, Schaad NW, Stead DE, Surico G and Ullrich MS (eds) Pseudomonas syringae and Related Pathogens. Biology and Genetics. Kluwer Academic Publishers, Dordrecht, pp 411-420.

Tobes R and Pareja E (2006) Bacterial repetitive extragenic palindromic sequences are DNA targets for insertion sequence elements. BMC Genomics 7:e62.

Van Zyl E and Steyn PL (1990) Differentiation of phytopathogenic Pseudomonas and Xanthomonas species and pathovars by numerical taxonomy and protein gel electrophoregrams. Syst Appl Microbiol 13:60-71.

Versalovic J, Koeuth T and Lupski RJ (1991) Distribution of repetitive DNA sequences in eubacteria and application to fingerprinting of bacterial genomes. Nucleic Acids Res 19:6823-6831.

Versalovic J, Schneider M, de Bruijn FJ and Lupski JR (1994) Genomic fingerprinting of bacteria using repetitive sequence-based PCR (rep-PCR). Methods Mol Cell Biol 5:25-40.

Vicente J and Roberts S (2007) Discrimination of Pseudomonas syringae isolates from sweet and wild cherry using rep-PCR. Eur J Plant Pathol 117:383-392.

Weingart H and Völksch B (1997) Genetic fingerprinting of Pseudomonas syringae pathovars using ERIC-, REP-, and IS50PCR. J Phytopathol 145:339-345.

Wilson LA and Sharp PM (2006) Enterobacterial repetitive intergenic concensus (ERIC) sequences in Escherichia coli: Evolution and implications for ERIC-PCR. Mol Biol Evol 23:1156-1168.

Woods CR, Versolovic J, Koeuth T and Lupski JR (1993) Whole-cell repetitive element sequence-based polymerase chain reaction allows rapid assessment of clonal relationship of bacterial isolates. J Clin Microbiol 31:1927-1931.

Young JM, Saddler GS, Takikawa Y, De Boer SH, Vauterin L, Gardan L, Gvozdyak R and Stead DE (1996) Names of plant pathogenic bacteria 1864-1995. Rev Plant Pathol $75: 721-763$

Associate Editor: Celia Maria de Almeida Soares

License information: This is an open-access article distributed under the terms of the Creative Commons Attribution License, which permits unrestricted use, distribution, and reproduction in any medium, provided the original work is properly cited. 